\title{
Mercury Biomagnification Through a Coral Reef Ecosystem
}

Darren G. Rumbold ${ }^{\mathrm{a}, *}$, Christopher T. Lienhardt ${ }^{\mathrm{a}}$, Michael L. Parsons ${ }^{\mathrm{a}}$

${ }^{a}$ Florida Gulf Coast University, 10501 FGCU Blvd. South. Fort Myers, FL 33965. USA

Darren Rumbold: drumbold@fgcu.edu

Christopher Lienhardt: ctlienha@eagle.fgcu.edu

Michael Parsons: mparsons@fgcu.edu

* Corresponding author: drumbold@fgcu.edu; 239 590-7527; https://orcid.org/0000-0003-2761-3635

\begin{abstract}
Total mercury $(\mathrm{Hg})$ and stable isotopes of nitrogen and carbon were determined in the muscle tissue of 50 species of fishes and invertebrates collected at two sites along the Florida reef tract from April 2012 - December 2013. The objective was to test the hypothesis that high biodiversity in coral reefs leading to complex food webs with increased lateral links reduces biomagnification. However, $\mathrm{Hg}$ levels ranged as high $6.84 \mathrm{mg} / \mathrm{kg}$. Interestingly, it was not highest in great barracuda (Sphyraena barracuda), considered the top predatory fish, but instead in small porkfish (Anisotremus virginicus), possibly due to their role as a cleaner fish. Trophic magnification slopes (TMS; from regression of $\log \mathrm{Hg}$ on $\delta^{15} \mathrm{~N}$ ) as a measure of biomagnification did not differ between sites, ranging from $0.155 \pm 0.04$ ( $\pm 95 \%$ confidence interval) to $0.201 \pm 0.07$. These TMS were also within the ranges of slopes reported for food webs in other ecosystems; thus, biomagnification of $\mathrm{Hg}$ in muscle tissue was not reduced in the system.
\end{abstract}

Keywords: mercury; trophic magnification slope; coral reef 


\section{Introduction}

Mercury $(\mathrm{Hg})$ is a persistent toxic metal that is a global problem due to its atmospheric residence time and long-range transport, deposition and eventual methylation by microbes (Driscoll et al. 2013). Exposure to methylmercury (MeHg), the organic form of $\mathrm{Hg}$ which biomagnifies through a food web, has a number of potential detrimental effects in humans (Oken et al. 2008; for review, see Karagas et al. 2012) and wildlife (Adams et al. 2010; Scheuhammer et al. 2015).

Factors controlling the biomagnification of $\mathrm{MeHg}$ and resulting concentrations occurring in apex predators are highly variable as evidenced by the occurrence of biological hotspots (i.e., "a location on the landscape that, compared to the surrounding landscape, is characterized by elevated concentrations of $\mathrm{Hg}$ in biota that exceed established human or wildlife health criteria" (Evers et al. 2007). These factors include variability in mass loading of inorganic $\mathrm{Hg}$, environmental conditions affecting biogeochemistry and net methylation rates, and the bioavailability of both inorganic and resulting organic forms (Evers et al. 2007; Chen et al. 2012; Heyes et al. 2006; Hollweg et al. 2010). Additionally, differences in community productivity and structure are thought to influence the degree of biomagnification. Primary and secondary production, species diversity, food chain length and complexity (i.e., number of trophic links per species) are all believed to be influential factors affecting biomagnification efficiency (Cabana et al. 1994; Stemberger and Chen 1998; Al-Reasi et al. 2007). For example, Cabana et al. (1994) found fish in lakes with longer food chains have higher $\mathrm{Hg}$ concentrations than fish from lakes with short food chains. In another study of fish from different lakes, Stemberger and Chen (1998) found $\mathrm{Hg}$ biomagnification was positively associated with food chain length; however, they also found concentrations were negatively correlated with the number of feeding links between species. They suggested that structurally complex food webs, comprising many lateral links, may attenuate the degree of biomagnfication due to pathways that do not lead to top predators (Stemberger and Chen 1998). Other studies have subsequently argued that lower biomagnification in certain ecosystems may be attributed to more complex food webs (Al-Reasi et al. 2007; Lavoie et al. 2013).

The number of studies of the influence community structure has on biomagnification have steadily increased over the past two decades with the application of the stable isotope approach (SIA) to quantify biomagnification through entire food webs (quantified as the trophic magnification slope from the linear regression of log transformed Hg concentration on $\delta^{15} \mathrm{~N}$; for review, see Jardine et al. 2006; Borgå et al. 2012). However, a recent world-wide meta- 
analysis of these studies (Lavoie et al. 2013) revealed that the majority have been conducted in temperate, freshwater lakes $(51 \%)$ as compared to tropical marine sites $(4 \%)$.

Coral reef communities, like those found in the Florida Keys, are among some of the most taxonomically diverse ecosystems in the world (Starck 1968). Starck (1968), for example, recorded 517 species at Alligator Reef, Florida that made it the richest known fauna in the "new world" at that time. As such, coral reefs with large choice of prey for a given consumer are ideal for investigating the effect that food web complexity has on biomagnification. Moverover, numerous adaptations and symbioses among autotrophs and mixotrophs lead to efficent recycling of nutrients that allows coral reefs to be some of the most biologically productive ecosystems while inhabiting waters that are generally low in nutirents (Odum and Odum 1955; Johannes et al. 1972). Although a limited number of studies have surveyed Hg concentrations in coral reef biota (Strom et al. 1992; Guzmán and Garcia 2002; Chouvelon et al. 2009; Berry et al. 2013; Morrison et al. 2015), to our knowledge, SIA has not been applied to these systems to assess their efficiency (vulnerability) for biomagnification.

The aim of the present study was to survey $\mathrm{Hg}$ concentrations and stable nitrogen isotopes across a range of trophic positions at two sites along the Florida reef tract to test the null hypothsis that there was no differnce in the biomagnfication efficiency (i.e., TMS) as compared to other ecosystems within the region (Hong et al. 2013; Thera and Rumbold 2014; Rumbold et al. 2018) and elsewhere ( Lavoie et al. 2013).

\section{Methods}

Study Area

Biota were collected from two sites within the Atlantic coastal waters of Long Key, Florida (Fig.1). This region lies along the Florida Straits and separates the Atlantic Ocean from the Gulf of Mexico. While the Florida Keys are characterized as subtropical based on their latitude, the marine fauna have been characterized as tropical (Starck 1968). Habitat at the two sites differed. The nearshore shallower site (4-5 m), designated as Long Key Hard Bottom (LKH), is located next to a channel marker (Channel 5; red \#44) and characterized by exposed hard substrate with soft-coral, sponge and macroalgal cover. The slightly deeper (6-7 m) offshore site, Tennessee Reef Lighthouse (TRL), is a bank reef with moderate cover of hard coral, soft-coral, sponge, and macroalgae on a sandy bottom. The reefs along Florida Keys are impacted by fishing and habitat degradation from other human activities (Cowie-Haskell and 
Delaney 2003). Water quality data from nearby sites (collected by others) are summarized in Supplemental Information (Supplemental Table S1).

\section{Sample Collection and Processing}

Samples were collected from April 2012 to December 2013 as part of a larger project investigating ciguatoxins bioaccumulating in reef fauna, with the sampling requirements of this larger study taking precedence. Sampling targeted a representative food web comprised of a variety of trophic levels and feeding guilds of invertebrates, e.g., suspension feeders and omnivores, and fishes, e.g., herbivores, invertebrate feeders and piscivores (Hoese and Moore 1998; feeding guilds based on Micheli et al. 2014). The result was an assortment of primary reef species and in-shore species (some of which exhibit an ontogenetic shift from coastal bays to offshore reefs; Starck 1968).

Collection methods included hook and line, spear-gun, hand collection by SCUBA divers and adhered to protocols approved by the University's Institutional Animal Care and Use Committee (IACUC). Sampling was done monthly. Once biota were returned to the boat they were placed in a labeled, ziplock-type plastic bag and immediately put on wet ice until returned to Florida Gulf Coast University for further processing.

Once back in the laboratory, organisms were identified to species or to the lowest practical taxonomic level using dichotomous key or identification guides (Hoese and Moore 1998). Fish were then weighed and measured using a measuring board or tape $( \pm 0.1 \mathrm{~cm})$ and digital balance $( \pm 0.1 \mathrm{~g})$ or Pesola spring scale $( \pm 10 \mathrm{~g})$. Muscle tissues were sampled from the left side of the fish above the lateral line and anterior to the dorsal fin, i.e., representative of a fillet, if collected for consumption by humans. Forage fish or secondary consumers were treated in an identical fashion with removal of a small amount of muscle tissue for analysis. Invertebrate samples were also measured (depending on the taxon; carapace length or width of crab species, or shell length of mollusks, i.e., longest axis depending on species) and weighed prior to the removal of soft inner tissues from the hard exoskeleton or shell (to ensure that similar sized individuals were repeatedly sampled); muscle tissue was sampled from invertebrates (rather than organs or homogenate). Ideally, trophic transfer studies should be based on whole-body concentration rather than just muscle tissue; however, attempting to obtain a representative sample from grinding up and homogenizing large game fish (which sometimes exceeded $130 \mathrm{~cm}$ and $14 \mathrm{~kg}$ in the present study) is somewhat impractical. Previous studies have combined Hg data from whole-body and muscle tissues (Riget et al. 2007; Chumchal et al. 2011; Karimi et al. 2013; 
Thera and Rumbold 2014; Rumbold et al. 2018). The present study opted for internal consistency and analyzed only muscle tissue. Although not tested here, this obviated any possible influence digestive tract contents might have had in $\mathrm{Hg}$ concentration (particularly in small organisms) and (as discussed below) likely reduced variability in the percent of THg as methylmercury particularly in invertebrates (Bloom 1992; Wiener et al. 2003).

All equipment was thoroughly rinsed with tap water then dried with a paper towel to remove excess tissue between samples. Upon completion, samples were frozen at $-20{ }^{\circ} \mathrm{C}$ in labeled scintillation vials and processed within 6 months.

Analytical Methods

Samples were analyzed for total mercury content ( $\mathrm{THg}$, i.e., all forms of $\mathrm{Hg}$ ) using a Nippon Model MA2000 (College Station, TX, USA). Briefly, known weights of wet tissues were loaded into sample boats then dried and thermally and chemically decomposed in Nippon's two-stage furnace. Scrubbed air then carried decomposition products to a gold amalgamator where they were concentrated until its temperature was raised to desorb the mercury vapors for quantification via atomic absorption spectrophotometry measured at $253.7 \mathrm{~nm}$ (i.e., EPA method 7473). Calibration curves were generated using varying masses of the following Certified Reference Materials (CRMs; National Research Council Canada, Institute for National Measurement Standards, Ottawa, ON, Canada): DOLT-3 (Dogfish Liver) or DORM-3 (Fish Protein) or DORM-4 (Fish Protein). These same CRMs, and in one case IAEA086 hair (International Atomic Energy Agency; Vienna, Austria), were also used for continuing calibration verification at the start and at the end of every batch of 20. Other quality control check samples run during each batch included blanks and duplicates. The correlation coefficient of initial calibration averaged $0.9989(\mathrm{n}=12)$; percent recovery of continuing calibration verification check samples was $103 \% \pm 15.4 \% \quad(n=60)$; relative percent difference (RPD) between laboratory duplicate analyses was $7.3 \pm 9 \%(n=31)$.

Much of the $\mathrm{Hg}$ in muscle tissues of higher trophic level fish (as opposed to whole fish) has been found to be in the methylated form (Grieb et al. 1990; Bloom 1992; Sveinsdottir and Mason 2005; Hammerschmidt and Fitzgerald 2006; Bank et al. 2007). Not surprisingly, because the analysis is more straightforward procedurally and less costly, THg is very often determined in fish tissues and generally considered a proxy for MeHg (Wiener et al. 2003; Farmer et al. 2010; Fry and Chumchal 2012). Alternatively, the percentage of THg that is $\mathrm{MeHg}($ i.e., $\% \mathrm{MeHg}$ ) is known to be much more variable and often lower in invertebrates, again depending on the tissue analyzed (Wiener 
et al. 2003; Chumchal et al. 2011; Apeti et al. 2012; Thera and Rumbold 2014). Accordingly, values of THg measured in the four species of collected invertebrates were adjusted to be equivalent to $\mathrm{MeHg}$ based on taxon-specific average \% MeHg reported for invertebrates by Thera and Rumbold (2014). That study quantified both MeHg and THg in gastropods, bivalves, crabs and shrimp. The taxon-specific ratios of THg:MeHg reported by Thera and Rumbold (2014) were consistent with average \% MeHg recently reported for eighteen species of mollusks and crustaceans as measured by USGS (Rumbold et al. 2017).

Tissue processing and analytical determination for stable isotopes of carbon and nitrogen followed previously published protocols (Jepsen and Winemiller 2002; Evers et al. 2009). Isotope ratios $\left({ }^{13} \mathrm{C} /{ }^{12} \mathrm{C}\right.$ and ${ }^{15} \mathrm{~N} /{ }^{14} \mathrm{~N}$ ) were determined on dried, acidified tissues at the University of California Davis Stable Isotope Facility (Davis, California, USA).

Stable isotope analysis (SIA) of nitrogen has previously been used to investigate trophic position and to assess the efficiency by which $\mathrm{Hg}$ biomagnifies through different food webs (for review, see Jardine et al. 2006). Previous studies have sometimes standardized $\delta^{15} \mathrm{~N}$ based on values in a local, primary consumer. This is particularly important where $\delta^{15} \mathrm{~N}$ signatures vary over space due to anthropogenic inputs (Chang et al. 2002). Those studies also sometimes translate $\delta^{15} \mathrm{~N}$ to trophic level using an average diet-tissue discrimination factor (or enrichment factor). This also allows for estimation of a food web magnification factor (FWMF, i.e., slope of logHg on trophic level) and basal Hg entering the food web based on the y-intercept. However, because of the growing debate about the choice of an "averaged" diet-tissue discrimination factor (Wolf et al. 2009; Matley et al. 2016) and since $\delta^{15} \mathrm{~N}$ signatures differed only slightly between food webs, the present study did not standardize or adjust $\delta^{15} \mathrm{~N}$ or estimate a FWMF. Standardizing the $\delta^{15} \mathrm{~N}$ changes the intercept but does not change the slopes (i.e., TMS). Rather than estimating basal Hg from the y-intercept of FWMF, which is very sensitive to the slope (Lavoie et al. 2013), we relied on Hg concentration measured in primary consumers.

\section{Data Analysis}

Unless otherwise noted, total- $\mathrm{Hg}$ concentration (hereafter designated as $[\mathrm{Hg}]$ ) was reported in $\mathrm{ng} / \mathrm{g}$ on a wet weight basis. [Hg] often increases with increasing fish size (intra-specifically; Karimi et al. 2013; Thera and Rumbold 2014) necessitating the use of analysis of covariance (ANCOVA) when making comparisons to partition the variance due to the covariate. However, use of ANCOVA is predicated on several critical assumptions, including sufficient 
sample size and range in the covariate that was not achieved in this study. Simple linear regression was used to examine how well the continuous variables, e.g., total length, $\delta^{15} \mathrm{~N}$, and $\delta^{13} \mathrm{C}$, explained the variance in [Hg] (based on the coefficient of determination, $\mathrm{r}^{2}$; presented in Supplemental Information). Assumptions of normality and equal variances were assessed first by Kolmorogov-Smirnov and Levene median test, respectively. Where necessary, [Hg] was $\log$ transformed to achieve normality or homogeneity of variance. Likewise, linear regression analysis was used to describe the relationship between $\log [\mathrm{Hg}]$ versus $\delta^{15} \mathrm{~N}$ for food webs at each site. ANCOVA was used to determine if slopes of these relationships (hereafter termed trophic magnification slope or TMS) differed. Data analyses were performed using Sigmaplot for Windows Version 11 software (Systat Software) or SPSS Statistics version 24 (IBM).

\section{Results}

A total of 242 samples of biota were collected from the two sites ( $\mathrm{n}=131$ at TRL and 111 at LKH) comprising 50 different species of mostly fishes but also 4 invertebrate species (Table 1 and 2). Each site was represented by 33 species with only 16 species captured at both sites; however, LKH had more species represented by a single individual. More importantly, despite efforts to balance sampling with regard to feeding guild, LKH was heavily represented by invertebrate feeding fish ( $70 \%$ based on individual data points, Table 2$)$ as compared to TRL where there was a higher representation of herbivores $(21 \%)$ and piscivores (24\%; Table 1). This bias was also evident in $\delta^{15} \mathrm{~N}$ clustered in the middle of the distribution at LKH (Table 1 and 2; Supplement Fig. S2).

All biota had measurable $[\mathrm{Hg}]$ in their tissues ranging as high as $6,842 \mathrm{ng} / \mathrm{g}$ in a porkfish (for species names, see Table 1 and 2) from TRL. Curiously, the next two highest observed [Hg] also occurred in porkfish (3,477 ng/g and $4,353 \mathrm{ng} / \mathrm{g}$ ) that were relatively small in size (average TL of these 3 fish was $20.4 \mathrm{~cm}$ ). By comparison, the next 7 highest $[\mathrm{Hg}]$ were observed in much larger great barracuda also from TRL (avg. TL = $109 \mathrm{~cm}$, Table 1).

A positive relationship between $\log [\mathrm{Hg}]$ and increasing TL was statistically significant for only two of seven fish species caught at TRL (where sample size was sufficient for analysis, $n \geq 5$; Supplemental Table S2): bluestriped grunt $\left(n=6, r^{2}=0.733, p=0.03\right)$ and great barracuda $\left(n=13, r^{2}=0.542, p=0.004\right)$. Three of six fish species at LKH (where $\mathrm{n} \geq 5$ ) exhibited a statistically significant relationship between $\log [\mathrm{Hg}]$ and TL (Supplemental Table S3): Bermuda chub $\left(n=10, r^{2}=0.397, p<0.05\right)$, porkfish $\left(n=5, r^{2}=0.732, p<0.05\right)$, and yellowtail snapper $\left(n=12, r^{2}=0.342, p<0.05\right)$.

Of the 16 species captured at both sites, only 5 were sampled in sufficient numbers ( $\mathrm{n} \geq 3$ ) to allow for statistical comparisons in $[\mathrm{Hg}]$ between locations: Bermuda chub, bluestriped grunt, hogfish, porkfish, and white 
grunt. Clearly these comparisons must be done cautiously and consider size distribution of the fish caught at the two sites. As reported above, none of sampled species exhibited a significant regression of $\log [\mathrm{Hg}]$ on TL at both sites that would allow for use of ANCOVA to partition the variance due to size differences. Accordingly, between-site differences in TL were assessed for each species prior to comparing $[\mathrm{Hg}]$. Neither fish TL or $[\mathrm{Hg}]$ differed statistically between sites in bluestriped grunts, porkfish, or hogfish (results presented in Supplemental Information). While both Bermuda Chub and white grunt caught at TRL were statistically larger than fishes from LKH (60\% and 24\% larger, respectively, Table 1 and 2), [Hg] did not differ significantly in fish between sites (results presented in Supplemental Information).

Between-site difference in $[\mathrm{Hg}]$ was also assessed in primary consumers (i.e., suspension-feeding bivalves): frond oysters from TRL ( $\mathrm{n}=5,34.32 \pm 4.0 \mathrm{ng} / \mathrm{g}$ ) and, to increase sample size, bivalves pooled across species from LKH (e.g., Atlantic wing oysters, $\mathrm{n}=3$; crested oyster, $\mathrm{n}=1$; frond oyster, $\mathrm{n}=1 ; 39.57 \pm 10.2 \mathrm{ng} / \mathrm{g}$ ). The between-site difference in $[\mathrm{Hg}]$ in these primary consumers, as a gauge of basal $\mathrm{Hg}$ entering the food web, was not statistically significant $(\mathrm{t}=-1.07, \mathrm{df}=8, \mathrm{p}=0.32)$. Interestingly, as reported below, sample size and statistical power was sufficient to discern a significant difference in $\delta^{15} \mathrm{~N}$ values in bivalves between the two sites (Mann-Whitney Rank Sum Test, $\mathrm{U}$ $=2.00, \mathrm{p}=0.03)$.

Cross-plots of $\delta^{15} \mathrm{~N}$ versus $\delta^{13} \mathrm{C}$ revealed interesting isotope signatures in biota from the two sites (Fig. S1). Invertebrates tended to be depleted in ${ }^{15} \mathrm{~N}$ compared to fish. The exceptions to this were spiny lobster and the Florida Horse conch (Fig. S1). The stoplight parrotfish (caught at TRL only) had the lowest average $\delta 15 \mathrm{~N}$ values for a fish and had mean $[\mathrm{Hg}]$ lower than that of the frond oysters (Table 1). Food web length was estimated by the range in mean $\delta^{15} \mathrm{~N}$ values (i.e., difference between mean $\delta^{15} \mathrm{~N}$ predatory fish and $\delta^{15} \mathrm{~N}$ invertebrate) to be $8.8 \%$ at TRL (great barracuda - frond oyster, Table 1) and 9.35\% at LKH (average of highest values from three species, each represented by 1 individual, - Atlantic wing oyster, Table 2).

Like the relation observed between $[\mathrm{Hg}]$ and $\mathrm{TL}$, larger fish within a population tended to be more enriched in ${ }^{15} \mathrm{~N}$ than smaller fish; however, the relationship was statistically significant only in blue tang (Supplemental Table S2 and S3). Although $\delta^{15} \mathrm{~N}$ differed in bivalves between sites (see above), $\delta^{15} \mathrm{~N}$ did not differ between sites in the five fish species common to both sites (where $\mathrm{n} \geq 3$ : Bermuda chub, bluestriped grunt, hogfish, porkfish, and white grunt; results presented in Supplemental Information). Stable isotopes of carbon $\left(\delta^{13} \mathrm{C}\right)$ were also analyzed in all samples to assess potential differences in carbon source (nearshore versus offshore, benthic versus pelagic) that might further 
explain observed variability in $[\mathrm{Hg}]$. While $\delta^{13} \mathrm{C}$ values were general lower in suspending feeding bivalves and herbivorous fish and more variable at LKH, they did not appear shifted as compared to TRL (Fig. S1). Only two of the 13 fish species analyzed (where $\mathrm{n} \geq 5$ ) showed a statistically significant relationship between $\delta^{13} \mathrm{C}$ and $\mathrm{Hg}$ : the blue $\operatorname{tang}\left(n=13, r^{2}=0.319, p=0.04\right.$, negative slope $)$ at TRL and the Bermuda chub $\left(n=10, r^{2}=0.428, p=0.04\right.$, positive slope) at LKH (Supplemental Table S2).

As expected, much of the interspecific variation in $[\mathrm{Hg}]$ was related to $\delta^{15} \mathrm{~N}$ (Table 1 and 2, Fig. 2). A statistically significant, positive relationship between $\log [\mathrm{Hg}]$ and $\delta^{15} \mathrm{~N}$ was evident at both locations (Fig. 2). To reduce potential bias resulting from disproportionate number of herbivores and piscivores at the two sites, trophic magnification slopes (i.e., TMS) were determined from regressions based on species means and estimated to be 0.201 \pm 0.07 ( $\pm 95 \%$ confidence interval) for TRL and $0.155 \pm 0.04$ for LKH. Slopes did not differ between sites, i.e., there was no interaction for $[\mathrm{Hg}]$ between sites and $\delta^{15} \mathrm{~N}$ as co-variate; ANCOVA F $\left.=1.41 ; \mathrm{df}=1,62 ; \mathrm{p}=0.24\right)$. When TMS were recalculated without invertebrate data, slopes increased to $0.235 \pm 0.08$ for TRL and $0.178 \pm 0.06$ for LKH.

\section{Discussion}

The biota from the present study contained $[\mathrm{Hg}]$ within the range of levels reported from previously surveys done in the Florida Keys (Strom et al. 1992; Adams et al. 2003; Huge et al. 2014; Tremain et al. 2014). Comparisons must be done with caution, however, due to differences in analytical methods, differences in species sampled and differences in size ranges of captured fish. For example, while the present study focused on sampling the entire food web, Adams et al. (2003) targeted game fish that are commonly harvested for human consumption. Furthermore, their study employed wet acid digestion rather than the thermal decomposition that was used in the present study. To improve comparability between the two analytical methods, data from Adams et al. (2003) were adjusted by multiplying values by 1.183 as suggested by Lowery et al. (2007) when comparing these two methods. Following this adjustment, average $[\mathrm{Hg}]$ observed in red groupers, black groupers, hogfish, gray snapper, and yellowtail snappers in the present study were similar or lower than levels in conspecifics sampled throughout the Keys from 1989-2001 by Adams et al. (2003). However, most of the fishes caught by Adams et al. (2003) were also larger than fishes in the present study. In contrast, barracuda caught in the present study were larger than barracuda caught by Adams et al. (2003) and contained higher $[\mathrm{Hg}]$. Similar to the results reported here, two recent surveys (both using the thermal 
decomposition method) reported finding $[\mathrm{Hg}]$ averaging less than $200 \mathrm{ng} / \mathrm{g}$ in lionfish from the Keys (Huge et al. 2014; Tremain et al. 2014).

Biota from the Keys also had $[\mathrm{Hg}]$ within the of range of levels reported in fishes collected from other areas of south Florida (Evans and Crumley 2005; Rumbold et al. 2018). For example, several fishes in the present study contained higher $[\mathrm{Hg}]$ than levels reported in conspecifics (e.g., Atlantic spadefish, gray snapper, lane snapper, leatherjacket) sampled at the mouth of Shark River Estuary in the coastal Everglades (Rumbold et al. 2018). Alternatively, gray snapper from nearby eastern Florida Bay contained much higher [Hg] (485 ng/g \pm 132 ng/g Hg, Evans and Crumley 2005). Florida Bay has, however, been characterized as a Hg hotspot (Rumbold et al. 2011). This characterization was recently supported by a study by Damseaux et al. (2016) that found $[\mathrm{Hg}]$ in bottlenose dolphins (Tursiops truncatus) to be higher in Florida Bay than the Keys and higher than levels reported in dolphins in the southeastern USA.

Nonetheless, the biota from the Keys contained higher $[\mathrm{Hg}]$ than levels reported from a limited number of surveys of reef biota from other locations (Plessi et al. 2001; Voegborlo and Akagi 2007; Chouvelon et al. 2009; Morrison et al. 2015). For example, $[\mathrm{Hg}]$ were higher in surgeonfish, goatfish and barracuda in the present study than similar species from fringe reefs in the remote Pacific near the American Samoan island of Tutuila (Morrison et al. 2015; after adjusting their wet weight concentrations from CVAF as outlined above). Likewise, chubs (Kyphosidae) and groupers (Serranidae) in the present study had high $[\mathrm{Hg}]$ than fishes surveyed along the coast of New Caledonia, despite being near potential point sources (Chouvelon et al. 2009).

It is also noteworthy that ten fish species from the Keys, including the porkfish and barracuda, contained $[\mathrm{Hg}]$ high enough to be of concern for human consumption (i.e., $\geq 300 \mathrm{ng} / \mathrm{g}$, USEPA 2001; Table 1 and 2).

The objective of this study was not simply to survey $[\mathrm{Hg}]$ in a few top predators and compare values to other areas but instead to examine the efficiency of biomagnification through the entire food web. As reasoned previously, with their high biodiversity, coral reef communities would seem an excellent choice to test the influence that structurally complex food webs with many lateral links has on $\mathrm{Hg}$ biomagnification. The trophic magnification slopes (TMS), as a measure of $\mathrm{Hg}$ biomagnification efficiency through the entire food web, were estimated to be $0.201 \pm 0.07$ and $0.155 \pm 0.04$ and did not differ between sites (when based on species means). Although slopes based on individual data points differed statistically, the regression for the LKH site was thought to be subject to sampling bias from fewer herbivores and piscivores at the bottom and top of the food web, respectively; whereas the slope at TRL was likely 
influenced heavily by the large number of sampled piscivores (particularly the barracuda). Accordingly, more weight was placed on the slopes based on species means at TRL.

The slopes from the present study were shallower than TMS values for food webs from Sarasota Bay (i.e., 0.27, Hong et al. 2013), near coastal waters off southwest Florida (i.e., 0.207, Thera and Rumbold 2014) and Shark River Estuary (0.23-0.241, Rumbold et al. 2018); although confidence intervals clearly overlapped. In their early review of the literature, Riget et al. (2007) noted the similarity in estimates of biomagnification efficiency among different ecosystems despite natural variability and differences among studies. This led some authors to suggest that spatial variation observed in bioaccumulated $\mathrm{Hg}$ may largely be a result of variability in the amount of MeHg entering the base of the food web (Riget et al. 2007; Chasar et al. 2009). Lavoie et al. (2013) were able to discern statistically significant patterns in TMS values from their world-wide meta-analysis (and resulting large data set), with higher values at polar and temperate sites when compared to tropical sites. They speculated that, among other factors, low species diversity and simpler food webs at higher latitudes might lead to higher Hg biomagnification (Lavoie et al. 2013). They reported a mean ( \pm 1 SD) TMS of $0.20 \pm 0.10$ for all marine sites and $0.16 \pm 0.08$ for just tropical marine sites (Lavoie et al. 2013) that are not appreciably different from the slopes observed here. Therefore, the results of the present study do not allow us to reject our null hypothesis that the TMS of a coral reef food web would not differ from other ecosystems.

Mercury biomagnification is affected by other variables besides species diversity, including food chain length and in situ physico-chemistry, e.g., nutrients, productivity, temperature, DOC (Watras et al. 1998; Pickhardt et al. 2002; Dittman and Driscoll 2009). Thus, the present study may not have been the best test of this hypothesis. For example, the length of the food chains in the present study appeared to be longer than other regional food chains based on range in $\delta^{15} \mathrm{~N}$ (Chasar et al. 2009; Hong et al. 2013; Thera and Rumbold 2014; Rumbold et al. 2018) and based on average range in trophic levels reported from the world-wide, meta-analysis by Lavoie et al. $(2013 ; 1.7 \pm 0.7$ versus 2.8 estimated for the present study using their equation 2). It is unclear whether a longer food chain may have offset any affect that increased feeding links between species may have had. Moreover, as mentioned previously, coral reefs are thought to be unusually efficient at retaining and recycling nutrients (Odum and Odum 1955; Johannes et al. 1972). Johannes et al. (1972), for example, found phosphorus recycling in coral communities "unusually efficient". Is it possible these adaptations allow them to retain and recycle other substrates like $\mathrm{Hg}$, thereby increasing the 
biomagnification efficiency. Clearly, we need more replicate studies on coral reefs before we can accept the null hypothesis.

As mentioned previously, the amount of $\mathrm{Hg}$ entering the base of the food web may play a dominant role in determining how much is biomagnified up to top predators. The present study gauged basal $\mathrm{Hg}$ from $[\mathrm{Hg}]$ observed in suspension feeding bivalves that ranged from $34.32 \pm 4.0 \mathrm{ng} / \mathrm{g}$ to $39.57 \pm 10.2 \mathrm{ng} / \mathrm{g}$ (wet wt.) and which did not differ between sites. The $[\mathrm{Hg}]$ in these bivalves was relatively high when compared to reports for bivalves from Sarasota Bay (7.1 to $13.4 \mathrm{ng} / \mathrm{g}$ wet wt.; Hong et al. 2013), hard-bottom habitat in near-coastal waters off SW Florida (8 ng/g wet wt.; Thera and Rumbold 2009) and Shark River Estuary (8.6 - 26 ng/g wet wt. Rumbold et al. 2018). It is well established that the concentrations of inorganic $\mathrm{Hg}$ in wet atmospheric and $\mathrm{Hg}$ deposition is high in south Florida (Rumbold et al. 2011), although wet deposition is somewhat lower in the Keys (Guentzel et al. 2001). Nonetheless, the $[\mathrm{Hg}]$ estimated to be entering the base of these food webs in hard-bottom and carbonate-sand environments is surprisingly high considering the influential factors thought to be affecting the activity of the methylating bacteria in sediments (for review, see Hollweg et al. 2010).

Another interesting and unexpected finding in the present study was the elevated $[\mathrm{Hg}]$ in the relatively small porkfish that often exceeded levels observed in much larger top predators like the great barracuda. Interestingly, porkfish have been reported participating in cleaning behavior (i.e., picking off and "cleaning" parasites off other fish) as juveniles but eventually change their feeding strategy (Bohlke and Chaplin 1968; Brockmann and Hailman 1976; Sazima et al. 2010). A diet associated with cleaning behavior was supported in the present study by finding harpacticoid copepods (possibly parasitic) in the stomach of the one porkfish. One could speculate that while acting as a cleaner fish, juvenile porkfish may have higher $\mathrm{Hg}$ exposure compared to older (larger) porkfish that no longer act as cleaners; smaller porkfish in the present study tended to have higher $[\mathrm{Hg}]$ than larger porkfish.

Clearly, this study had several limitations and has left many questions unanswered. First, like many other studies (e.g., 127 studies summarized in Lavoie et al. 2013), we quantified biomagnification and TMS based on total$\mathrm{Hg}$ rather than $\mathrm{MeHg}$. As previously discussed, \% MeHg is known to vary depending on tissue type, trophic level and [Hg] (Wiener et al. 2003; Seixas et al. 2013; Morrison et al. 2015). Thus, this continued reliance on total-Hg as a proxy of MeHg introduced uncertainty and variance in the TMS. Nonetheless, the results of this study will hopefully stimulate and inform the design of future research. These future studies should be based on MeHg rather than total$\mathrm{Hg}$, target more invertebrates possibly including coral tissues and strive for more balanced sampling. Moreover, 
natural variability could be better controlled by targeting certain size fish or collecting sufficient samples and size ranges to allow for ANCOVA, perhaps targeting primary reef species over in-shore species. Continued monitoring of $\mathrm{Hg}$ levels in these predatory fish, especially species targeted by recreational anglers, is warranted since $[\mathrm{Hg}]$ in 10 species exceeded the benchmark for issuing consumption advisories. The source of the MeHg entering the base of the food web should be determined. At this point, there is no information on whether mercury methylation occurred in the calcium carbonate sediments; however, we cannot rule it out nor rule out the possibility that methylation might be occurring in the water column or even within sponges for that matter (cf. Hoffmann et al. 2009). Finally, the surprisingly high $[\mathrm{Hg}]$ in the porkfish also warrants attention for future studies to determine if the levels were a result of the cleaner behavior.

\section{Appendix 1. Supplementary Information}

Supplementary data to this article (Tables S1-S3 and Figures S1-S2) can be found in Appendix 1.

\section{Acknowledgments:}

We would like to thank FGCU students that provided field or laboratory support on this project as paid interns or volunteers, including: Alex Leynse, Amanda Ellsworth, Ashley Brandt, Nicole Fronczkowski, Megan Conkling, Adam Catasus, and Jeff Zingre. We would also like to thank Curt Slonim for his assistance in catching and providing many of the great barracuda from TRL. Finally, we thank two anonymous reviewers for their comments that improved this manuscript. Funding for this work was provided by an internal grant from Florida Gulf Coast University, Office of Sponsored Programs. Additionally, we also split samples and leveraged fieldwork of a much larger study (by Parsons) investigating biomagnification of ciguatoxins funded through NOAA's Ecology and Oceanography of Harmful Algal Blooms (ECOHAB) Program. The authors declare that they have no conflict of interest. 
Fig. 1. Map of study area showing collection sites off Long Key, Florida

Fig. 2. Relationship between log $[\mathrm{Hg}](\mathrm{ng} / \mathrm{g}$, wet weight) and $\delta 15 \mathrm{~N}(\% \circ)$ from two sites along the Florida Reef tract: (top panel) Tennessee Reef Light (TRL) and (bottom panel) Long Key Hard Bottom (LKH) with trophic magnification slopes estimated from regression on species means. 


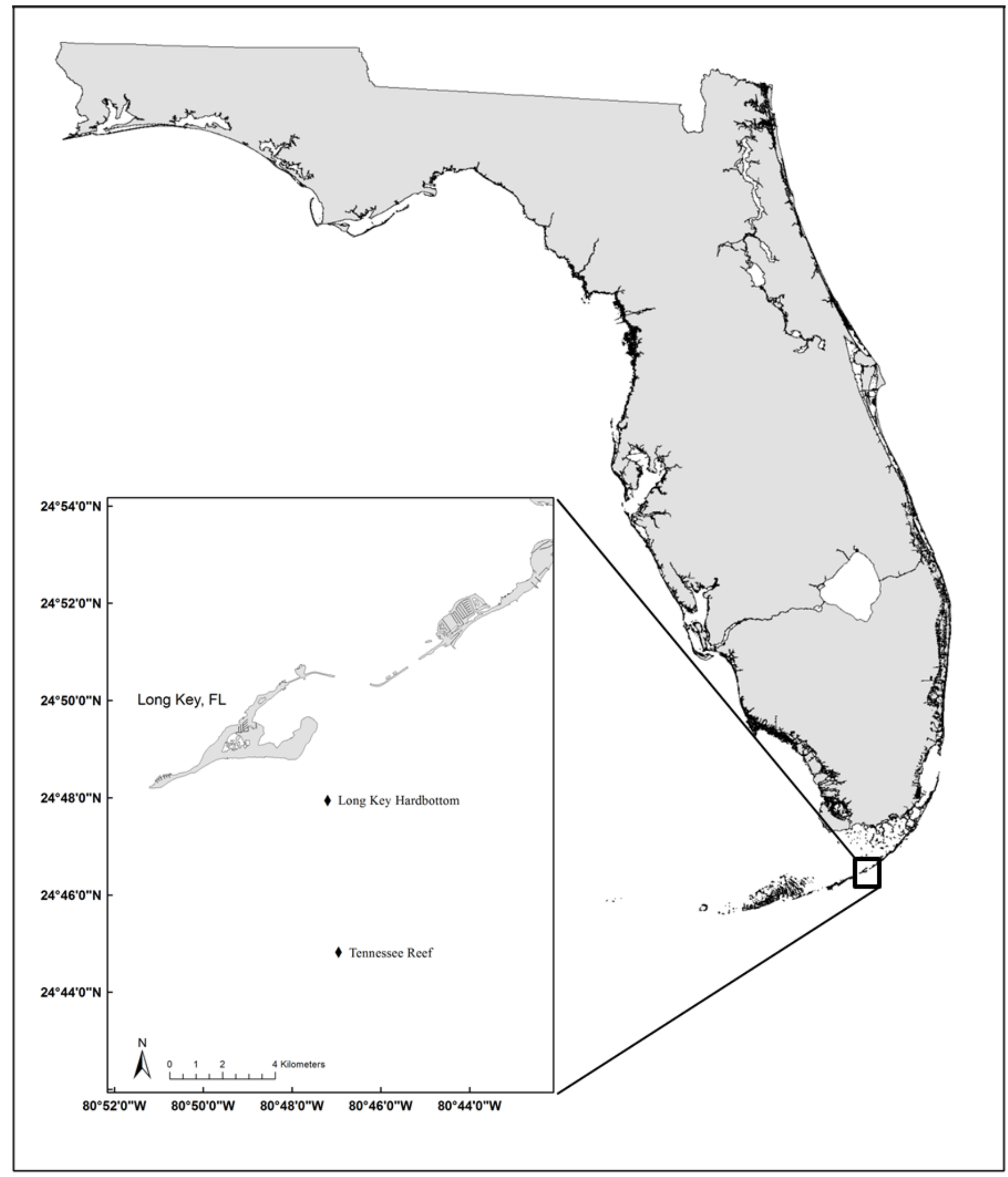



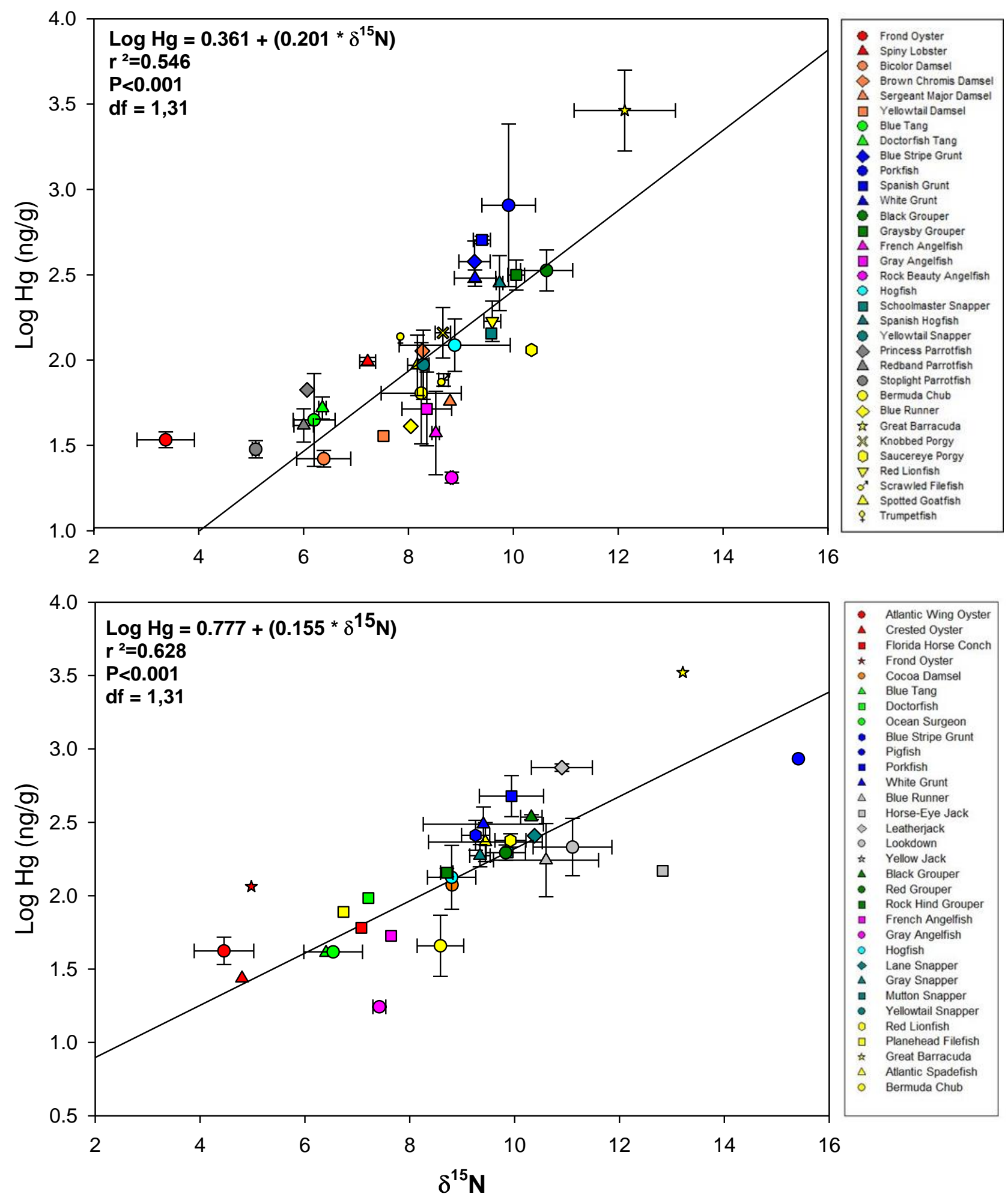
Table 1 Metadata for biota collected from Tennessee Reef Light (TRL) including common name, species, reported feeding guild (adapted from Micheli et al. 2014), total length, [Hg], and values for stable isotopes of $\delta 13 C$ and $\delta 15 N$.

Table 2 Metadata for biota collected from Long Key Hard Bottom (LKH) including common name, species, reported feeding guild (adapted from Micheli et al. 2014), total length, [Hg], and values for stable isotopes of $\delta 13 C$ and 815N. 


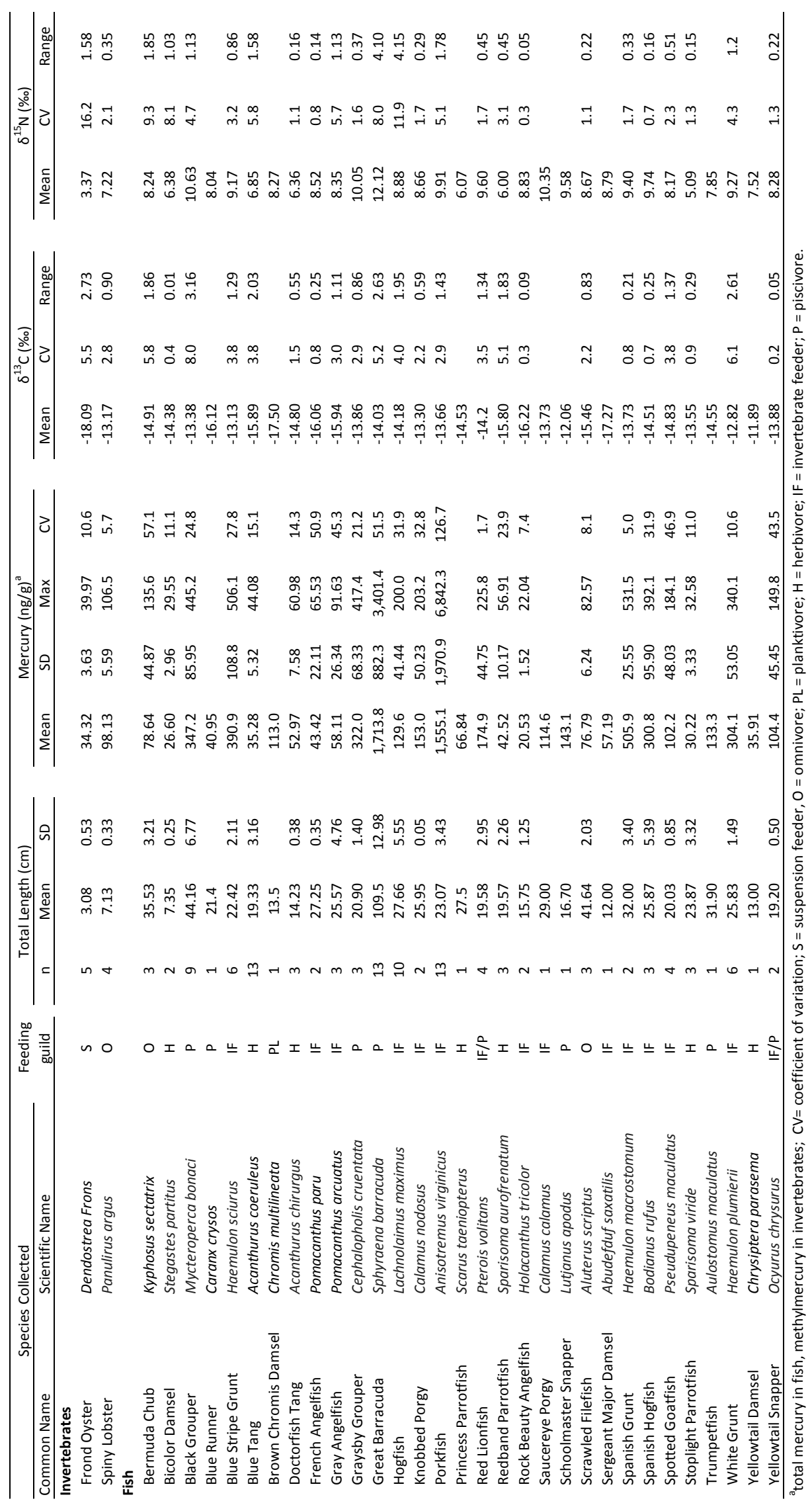




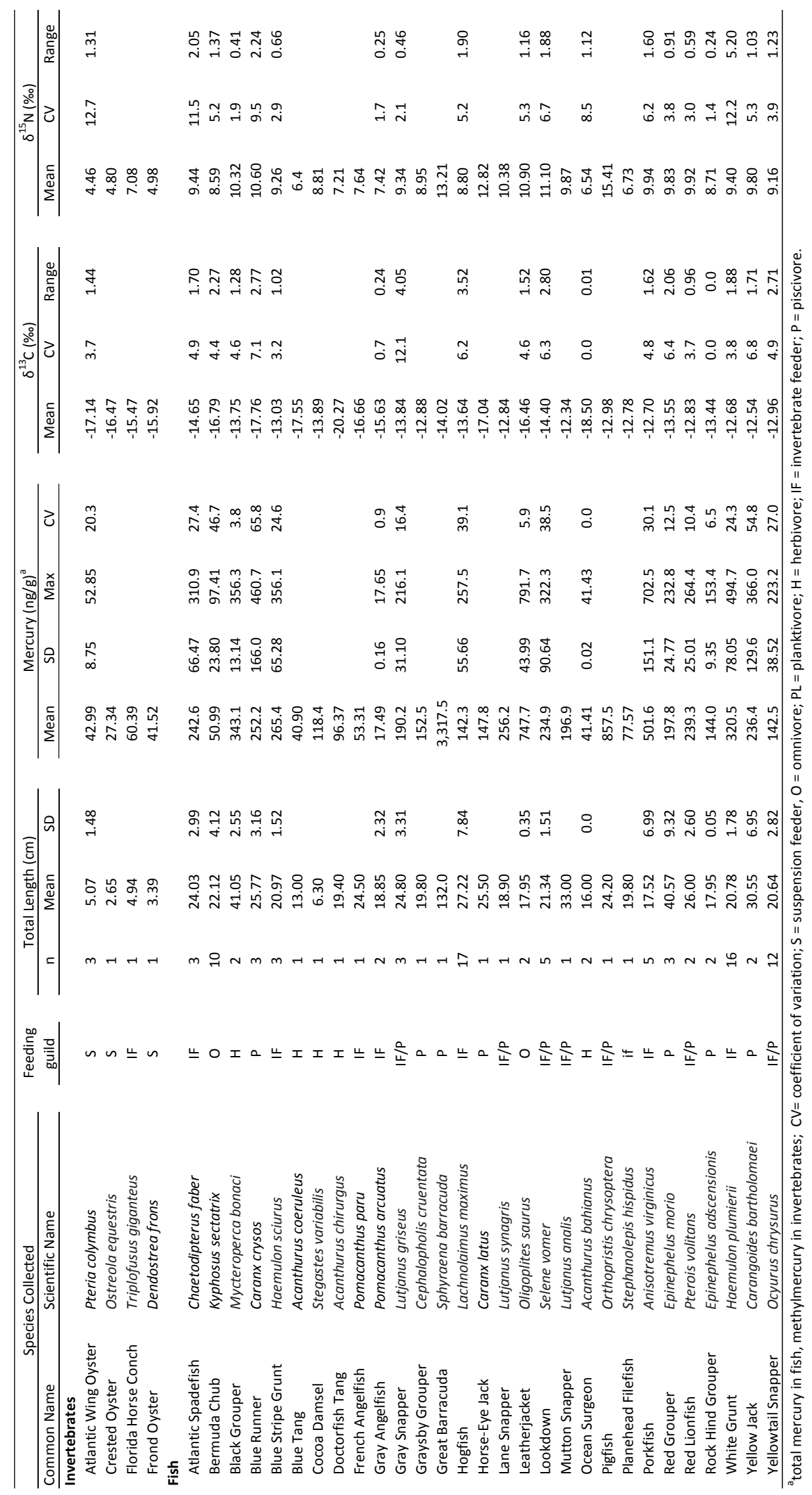




\section{Literature Cited}

Adams DH, McMichael RH Jr, Henderson GE (2003) Mercury levels in marine and estuarine fishes of Florida 1989-2001 Florida Marine Research Institute Technical Report TR-9 2nd ed rev 57 pp

Adams DH, Sonne C, Basu N, et al. (2010) Mercury contamination in spotted seatrout, Cynoscion nebulosus: An assessment of liver, kidney, blood, and nervous system health. Sci Total Environ 408(23):5808-5816

Al-Reasi HA, Ababneh FA, Lean DR (2007) Evaluating mercury biomagnification in fish from a tropical marine environment using stable isotopes $(\delta 13 \mathrm{C}$ and $\delta 15 \mathrm{~N})$. Environmental Toxicology and Chemistry 26(8):1572-1581

Apeti D, Lauenstein G, Evans D (2012) Recent status of total mercury and methyl mercury in the coastal waters of the northern Gulf of Mexico using oysters and sediments from NOAA's mussel watch program. Mar Poll Bull 64: 2399-2408

Bank MS, Chesney E, Shine JP, Maage A, Senn DB (2007) Mercury bioaccumulation and trophic transfer in sympatric snapper species from the Gulf of Mexico. Ecol Appl 17(7), 2100-2110

Berry KL, Seemann J, Dellwig O, Struck U, Wild C, Leinfelder RR (2013) Sources and spatial distribution of heavy metals in scleractinian coral tissues and sediments from the Bocas del Toro Archipelago, Panama. Environ Monitor Assess 185:9089-9099

Bloom NS (1992) On the chemical form of mercury in edible fish and marine invertebrate tissue. Can J Fish Aquat Sci 49:1010-1017

Brockmann HJ, Hailman JP (1976) Fish cleaning symbiosis: notes on juvenile angelfishes (Pomacanthus, Chaetodontidae) and comparisons with other species. Ethol 42:129-138

Bohlke JE, Chaplin CCG (1968) Fishes of the Bahamas and adjacent waters. Livingston Publication Co Wynnewood, Pennsylvania

Borgå K, Kidd KA, Muir DC, Berglund O, Conder JM, Gobas FA, Kucklick J, Malm O, Powell DE (2012) Trophic magnification factors: considerations of ecology, ecosystems, and study design. Integr Environ Assess Manag 8(1), 64-84

Cabana G, Tremblay A, Kalff J, Rasmussen JB (1994) Pelagic food chain structure in Ontario lakes: a determinant of mercury levels in lake trout (Salvelinus namaycush), Can J Fish Aquat Sci 51(2): 381-389

Chang CC, Kendall C, Silva SR, Battaglin WA, Campbell DH (2002) Nitrate stable isotopes: tools for determining nitrate sources among different land uses in the Mississippi River Basin. Canadian Journal of Fisheries and Aquatic Sciences 59(12):1874-1885

Chasar LC, Scudder BC, Stewart AR, Bell AH, Aiken GR (2009) Mercury cycling in stream ecosystems 3. Trophic dynamics and methylmercury bioaccumulation. Environ Sci Technol 43(8):2733-2739

Chen CY, Driscoll CT, Kamman NC (2012) Mercury hotspots in freshwater ecosystems: drivers, processes, and patterns In Mercury in the Environment: Pattern and Process, Bank, M C, Ed; University California Berkeley Press: Berkeley, California, 2012

Chouvelon T, Warnau M, Churlaud C, Bustamante P (2009) Hg concentrations and related risk assessment in coral reef crustaceans, molluscs and fish from New Caledonia. Environ Pollut 157(1):331-340

Chumchal MM, Rainwater TR, Osborn SC, et al. (2011) Mercury speciation and biomagnification in the food web of Caddo Lake, Texas and Louisiana, USA, a subtropical freshwater ecosystem. Environmental Toxicology and Chemistry 30(5):1153-1162

Cowie-Haskell BD, Delaney JM (2003) Integrating science into the design of the Tortugas ecological reserve. Mar Technol Soc J 37: 1-14 
Damseaux F, Kiszka JJ, Heithaus MR, et al. (2017) Spatial variation in the accumulation of POPs and mercury in bottlenose dolphins of the Lower Florida Keys and the coastal Everglades (South Florida). Environ Pollut 220:577587

Dittman JA, Driscoll CT (2009) Factors influencing changes in mercury concentrations in lake water and yellow perch (Perca flavescens) in Adirondack lakes. Biogeochemistry 93(3):179-196

Driscoll CT, Mason RP, Chan HM, Jacob DJ, Pirrone N (2013) Mercury as a global pollutant: sources, pathways, and effects. Environ Sci Technol 47 (10):4967-4983

Evans DW, Crumley PH (2005) Mercury in Florida Bay fish: spatial distribution of elevated concentrations and possible linkages to Everglades restoration. Bull Mar Sci 77(3): 321-346

Evers DC, Graham RT, Perkins CR, Michener R, Divoll T (2009) Mercury concentrations in the goliath grouper of Belize: an anthropogenic stressor of concern. Endangered Species Research 7:249-256

Evers DC, Han Y-J, Driscoll CT, et al. (2007) Biological mercury hotspots in the northeastern United States and southeastern Canada. BioScience 57:29-43

Farmer TM, Wright RA, DeVries DR (2010) Mercury concentration in two estuarine fish populations across a seasonal salinity gradient. Trans Am Fish Soc 139:1896-1912

Fry B, Chumchal MM (2012) Mercury bioaccumulation in estuarine food webs. Ecol App 22:606-623

Grieb TM, Driscoll CT, Schofield CL, Bowie GL, Porcella DB (1990) Factors affecting mercury accumulation in fish in the upper Michigan peninsula. Environ Toxicol Chem 9:919-930

Guentzel JL, Landing WM, Gill GA, Pollman CD (2001) Processes influencing rainfall deposition of mercury in Florida. Environ Sci Technol 35:863-873

Guzmán HM, García EM (2002) Mercury levels in coral reefs along the Caribbean coast of Central America. Mar Pollut Bull 44:1415-1420

Hammerschmidt C, Fitzgerald W (2006) Bioaccumulation and trophic transfer of methylmercury in Long Island Sound. Arch Environ Contam Toxicol 51(3):416-424

Heyes A, Mason RP, Kim EH, Sunderland E (2006) Mercury methylation in estuaries: Insights from using measuring rates using stable mercury isotopes. Mar Chem 102:134-147

Hoffmann F, Radax R, Woebken D, et al. (2009) Complex nitrogen cycling in the sponge Geodia barretti Environ Microbiol 11(9):2228-2243

Hoese H, Moore R (1998) Fishes of the Gulf of Mexico, Texas, Louisiana, and adjacent waters (2nd ed) College Station: Texas A and M University Press

Hollweg T, Gilmour CC, Mason R (2010) Mercury and methylmercury cycling in sediments of the mid-Atlantic continental shelf and slope. Limnol Oceanogr 55:2703-2722

Hong YS, Hull P, Rifkin E, Bouwer EJ (2013) Bioaccumulation and biomagnification of mercury and selenium in the Sarasota Bay ecosystem. Environ Toxicol Chem 32:1143-1152

Huge DH, Schofield PJ, Jacoby CA, Frazer TK (2014) Total mercury concentrations in lionfish (Pterois volitans/miles) from the Florida Keys National Marine Sanctuary, USA. Mar Pollut Bull 78(1):51-55

Jardine TD, Kidd KA, Fisk AT (2006) Applications, considerations, and sources of uncertainty when using stable isotope analysis in ecotoxicology. Environ Sci Technol 40:7501-7511

Jepsen DB, Winemiller KO (2002) Structure of tropical river food webs revealed by stable isotope ratios. Oikos 96(1):46-55 
Johannes R, Alberts J, D'elia C, et al. (1972) The metabolism of some coral reef communities: a team study of nutrient and energy flux at Eniwetok. BioScience 22(9):541-543

Karimi R, Frisk M, Fisher NS (2013) Contrasting food web factor and body size relationships with Hg and Se concentrations in marine biota. PLoS ONE 8(9):e74695

Kidd KA, Clayden M, Jardine T (2012) Bioaccumulation and biomagnification of mercury through food webs. Environmental Chemistry and Toxicology of Mercury Wiley, Hoboken, 455-499

Lavoie RA, Jardine TD, Chumchal MM, Kidd KA, Campbell LM (2013) Biomagnification of Mercury in Aquatic Food Webs: A Worldwide Meta-Analysis. Environ Sci Technol 47(23):13385-13394

Lowery TA, Winters RS, Garrett ES III (2007) Comparison of total mercury determinations of fish fillet homogenates by thermal decomposition, amalgamation, and atomic absorption spectrophotometry versus cold vapor atomic absorption spectrophotometry. J Aquat Food Prod Technol 16(2):5-15

Matley J, Fisk A, Tobin A, Heupel M, Simpfendorfer C (2016) Diet- tissue discrimination factors and turnover of carbon and nitrogen stable isotopes in tissues of an adult predatory coral reef fish, Plectropomus leopardus. Rapid Commun Mass Spectrom 30:29-44

Micheli F, Mumby PJ, Brumbaugh DR, et al. (2014) High vulnerability of ecosystem function and services to diversity loss in Caribbean coral reefs. Biol Conser 171:186-194

Morrison RJ, Peshut PJ, West RJ, Lasorsa BK (2015) Mercury (Hg) speciation in coral reef systems of remote Oceania: Implications for the artisanal fisheries of Tutuila, Samoa Islands. Mar Poll Bull 96 (1):41-56

Odum HT, Odum EP (1955) Trophic structure and productivity of a windward coral reef community on Eniwetok Atoll. Ecol Monographs 25:291-320

Karagas MR, Choi AL, Oken E, et al. (2012) Evidence on the human health effects of low-level methylmercury exposure. Environmental Health Perspectives 120(6):799-806

Pickhardt PC, Folt CL, Chen CY, Klaue B, Blum JD (2002) Algal blooms reduce the uptake of toxic methylmercury in freshwater food webs. Proceedings of the National Academy of Sciences 99(7):4419-4423

Plessi M, Bertelli D, Monzani A (2001) Mercury and selenium content in selected seafood. J. Food Composition and Analysis 14(5):461-467

Riget F, Moller P, Dietz R, Nielsen TG, Asmund G, Strand J, Larsen MM, Hobson KA (2007) Transfer of mercury in the marine food web of West Greenland. J Environ Monit 9:877-883

Rumbold DG, Evans DW, Niemczyk S, Fink LE, Laine KA, Howard N, Krabbenhoft D, Zucker M (2011) Source identification of Florida Bay's methylmercury problem: Mainland runoff versus atmospheric deposition and in situ production Estuar Coast 34(3):494-513

Rumbold DG, Lange TR, Richard D, DelPizzo G, Hass N (2018) Mercury biomagnification through food webs along a salinity gradient down-estuary from a biological hotspot. Estuar Coast Shelf Sci 200:116-125

Sazima C, Guimarães PR, Dos Reis SF, Sazima I (2010) What makes a species central in a cleaning mutualism network? Oikos 119(8):1319-1325

Scheuhammer A, Braune B, Chan HM, et al. (2015) Recent progress on our understanding of the biological effects of mercury in fish and wildlife in the Canadian Arctic. Sci Total Environ 509:91-103

Seixas TG, Moreira I, Malm O, Kehrig HA (2013) Ecological and biological determinants of methylmercury accumulation in tropical coastal fish. Environ Sci Pollut Res 20(2):1142-1150 
Starck W (1968) A list of fishes of Alligator Reef, Florida with comments on the nature of the Florida reef fish fauna. Undersea Biol 1:4-40

Stemberger RS, Chen CY (1998) Fish tissue metals and zooplankton assemblages of northeastern US lakes. Can J Fish Aquat Sci 55(2):339-352

Strom RN, Braman RS, Jaap WC, Dolan P, Donnelly KB, Martin DF (1992) Analysis of selected trace metals and pesticides offshore of the Florida Keys. Florida Scientist 55:1-13

Sveinsdottir AY, Mason RP (2005) Factors controlling mercury and methylmercury concentrations in largemouth bass (Micropterus salmoides) and other fish from Maryland reservoirs. Arch Environ Contam Toxicol 49:528-545

Thera JC, Rumbold DG (2014) Biomagnification of mercury through a subtropical coastal food web off Southwest Florida. Environ Toxicol Chem 33(1):65-73

Tremain DM, O'Donnell KE (2014) Total mercury levels in invasive lionfish, Pterois volitans and Pterois miles (Scorpaenidae), from Florida waters. Bull Mar Sci 90(2):565-578

USEPA (2001) Water Quality Criterion for the Protection of Human Health: Methylmercury Office of Science and Technology and Office of Water EPA/823/R-01-001 Washington, DC, USA

Voegborlo RB, Akagi H (2007) Determination of mercury in fish by cold vapour atomic absorption spectrometry using an automatic mercury analyzer. Food Chemistry 100(2):853-858

Watras CJW, Back RC, Halvorsena S, Hudson RJM, Morrison KA, Wente SP (1998) Bioaccumulation of mercury in pelagic freshwater food webs. Sci Total Environ 219:183-208

Wiener JG, Krabbenhoft DP, Heinz GH, Scheuhammer AM (2003) Ecotoxicology of mercury. Handbook of Ecotoxicology 2:409-463

Wolf N, Carleton SA, Martínez del Rio C (2009) Ten years of experimental animal isotopic ecology. Functional Ecology 23:17-26 